\title{
Evaluation of tests to assess the quality of mine-contaminated soils
}

\author{
P. Alvarenga $\cdot$ P. Palma $\cdot$ A. P. Gonçalves $\cdot$ R. M. Fernandes $\cdot$ \\ A. de Varennes $\cdot$ G. Vallini $\cdot$ E. Duarte $\cdot$ A. C. Cunha-Queda
}

Received: 13 October 2006 / Accepted: 18 May 2007 / Published online: 2 February 2008

(C) Springer Science+Business Media B.V. 2008

\begin{abstract}
An acid metal-contaminated soil from the Aljustrel mining area (a pyrite mine located in SW Portugal in the Iberian Pyrite Belt) was subjected to chemical characterisation and total metal quantification $(\mathrm{Cd}, \mathrm{Cr}, \mathrm{Cu}, \mathrm{Ni}, \mathrm{Pb}$ and $\mathrm{Zn}$ ). Water-soluble metals were determined and a sequential extraction procedure was used to investigate metal speciation. Two bioavailable metal fractions were determined: a mobile fraction and a mobilisable fraction. Soil ecotoxicity was studied using a battery of bioassays: plant growth test and seed germination with cress (Lepidium sativum L.), earthworm (Eisenia fetida) mortality, E. fetida avoidance behaviour, luminescent inhibition of Vibrio fischeri and Daphnia magna immobilisation. Although the total content of $\mathrm{Cu}, \mathrm{Zn}$
\end{abstract}

P. Alvarenga $(\bowtie) \cdot$ P. Palma · A. P. Gonçalves ·

R. M. Fernandes

Departamento de Ciências do Ambiente, Escola Superior

Agrária de Beja, Rua Pedro Soares, Apartado 158,

7801-902 Beja, Portugal

e-mail: paula.alvarenga@esab.ipbeja.pt

A. de Varennes · E. Duarte · A. C. Cunha-Queda Departamento de Química Agrícola e Ambiental, Instituto Superior de Agronomia, Universidade Técnica de Lisboa (TULisbon), Tapada da Ajuda, 1349-017 Lisboa, Portugal

G. Vallini

Department of Science and Technology, Laboratories of Microbial Biotechnology and Environmental Microbiology, University of Verona, Strada Le Grazie 15, Ca’ Vignal, 37134 Verona, Italy and $\mathrm{Pb}$ in the soil was large $(362,245$ and $1,250 \mathrm{mg} /$ $\mathrm{kg}$ dry matter, respectively), these metals were mostly structurally bound $(87 \%$ for $\mathrm{Cu}, 81 \%$ for $\mathrm{Zn}$ and $89 \%$ for $\mathrm{Pb}$ ) and, therefore, scarcely bioavailable. Nonetheless, the D. magna immobilization test using soil leachate showed an $\mathrm{EC}_{50}(48 \mathrm{~h})$ of $36.3 \%(\mathrm{v} / \mathrm{v})$, and the luminescent inhibition of $V$. fischeri presented an $\mathrm{EC}_{20}(15 \mathrm{~min})$ of $45.2 \%$ and an $\mathrm{EC}_{20}(30 \mathrm{~min})$ of $10.7 \%(\mathrm{v} / \mathrm{v})$, suggesting a considerable toxic effect. In the direct exposure bioassays, E. fetida avoided the mine soil at the highest concentrations (50\%, 75\% and $100 \% \mathrm{v} / \mathrm{v})$. At the same soil concentrations, cress showed negligible growth. The results suggest the need to use a battery of toxicity tests, in conjunction with chemical methods, in order to assess the quality of mine-contaminated soils correctly.

Keywords Bioassays - Bioavailability ·

Metal-contaminated soil · Single and sequential extraction procedures

\section{Introduction}

Soils are systems in which a dynamic equilibrium exists between the total content of metals, the mobile fraction (soluble, very active and bioavailable) and the mobilisable fraction (potentially bioavailable, leachable and partly active) (Gupta et al. 1996). Over the last 30 years, single and sequential extraction protocols have been designed to predict both the 
retention and release of metals in soils, sediments and sludges and their bioavailability (Tessier et al. 1979; Quevauviller et al. 1996; Kennedy et al. 1997; Rauret et al. 2000; Sahuquillo et al. 2003). However, these methods are empirical and can only estimate the potential availability of elements for plant uptake (Kennedy et al. 1997) or the form of a specific metal in the matrix of interest. Furthermore, the results are highly dependent on the extraction protocol used (Rauret et al. 2000). For these reasons, chemical analyses are seldom suited for the evaluation of potential ecological risks, since they do not take into account the possible combined effects of different contaminants, as well as their bioavailability. Bioassays, which can overcome these constraints, are therefore recommended for the assessment of ecological risks in soils (van Gestel et al. 2001).

The aims of this study were: (i) to assess the chemical and ecotoxicological characteristics of a minecontaminated soil and (ii) to evaluate which bioassays are more reliable indicators of ecotoxicity and convenient to use in this type of soil.

\section{Materials and methods}

Topsoil $(0-20 \mathrm{~cm})$ from a metal-contaminated site in the Aljustrel mining area (a pyrite mine located in SW Portugal in the Iberian Pyrite Belt) was subjected to chemical characterisation and total heavy metal quantification $(\mathrm{Cd}, \mathrm{Cr}, \mathrm{Cu}, \mathrm{Ni}, \mathrm{Pb}$ and $\mathrm{Zn})$ by atomic absorption spectrometry (AAS) after digestion with aqua regia (ISO 11466 1995). Water-soluble metals were determined according to DIN 38 414-S4 (1984), using a batch test with a single leaching cycle (distilled water in a $1: 10 \mathrm{~m} / \mathrm{v}$ solid-to-liquid ratio, $24 \mathrm{~h}$ under constant agitation, room temperature). The Community Bureau of Reference (BCR) sequential extraction procedure, used for heavy metal speciation, was performed as described by Rauret et al. (2000): first step-extraction of soil samples with acetic acid $0.11 \mathrm{~mol}^{-1}$ to liberate exchangeable/acid-extractable metals; second step-metals associated with the reducible phases were then solubilised using hydroxylamine hydrochloride; third step-the contaminants released by oxidation with hydrogen peroxide were extracted in $0.1 \mathrm{~mol}^{-1}$ ammonium acetate, and finally the residual metal content was determined by digestion with aqua regia. Bioavailable metal fractions were determined using two different single step extractions: a mobile fraction (extracted by 0.01 $\mathrm{M} \mathrm{CaCl}_{2}, \mathrm{pH}$ 5.7, without buffer) (Houba et al. 1996; Pueyo etal. 2004) and a mobilisable fraction (extracted by a solution of $0.5 \mathrm{M} \mathrm{NH}_{4} \mathrm{CH}_{3} \mathrm{COO}, 0.5$ $\mathrm{M} \mathrm{CH}_{3} \mathrm{COOH}$ and 0.01 M EDTA, pH 4.7) (Hammer and Keller 2002). Extractions were performed by $2 \mathrm{~h}$ horizontal reciprocate shaking, using a 1:10 (w/v) soil to solution ratio at room temperature. The extract was separated from the solid residue by centrifugation at 3,000 $\mathrm{g}$ for $10 \mathrm{~min}$. Soil ecotoxicity was studied using a battery of bioassays. Direct toxicity bioassays were performed using the sampled soil and dilutions with an artificial soil (1/3 peat:1/3 sand:1/3 perlite, $\mathrm{pH}$ $4.5)$, which was also used as control. The indirect exposure bioassays were performed using leachates, obtained by the method DIN 38 414-S4 (1984), as previously described, and dilutions with distilled water. Direct acute toxicity bioassays were: plant growth test with cress (Lepidium sativum L.) (ISO/ DIS 15799 1999) and earthworm (Eisenia fetida) mortality (ASTM E 1676-97,1997). E. fetida was also used in an avoidance behaviour response bioassay, in order to evaluate the subchronic toxicity of the soil (ISO/CD 2003). Indirect acute toxicity bioassays, with leachate from the soil, comprised: luminescent inhibition of Vibrio fischeri (ISO 11348-2 1998), Daphnia magna immobilization (ISO 6341 1996) and seed germination (L. sativum) (Fuentes et al. 2004).

Data were submitted to analysis of variance (ANOVA) and the means compared by the Tukey's range test $(p<0.05)$ or the Dunnet's test for comparison with a control group $(p<0.05)$. The $\mathrm{EC}_{20}$ and $\mathrm{EC}_{50}$ values were calculated using the trimmed Spearman-Karber method (Hamilton et al. 1977).

\section{Results}

\section{Metal concentrations}

The soil was a sandy loam $\left(704 \mathrm{~g} \mathrm{~kg}^{-1}\right.$ sand, $177 \mathrm{~g} \mathrm{~kg}^{-1}$ silt and $119 \mathrm{~g} \mathrm{~kg}^{-1}$ clay), acid $\left(\mathrm{pH}_{\mathrm{H} 20}=3.6\right)$, with low salinity $\left(\mathrm{EC}=0.021 \mathrm{~S} \mathrm{~m}^{-1}\right)$, low cation exchange capacity $\left(8.6 \mathrm{cmol} \mathrm{kg}^{-1}\right)$, poor in organic matter $(\mathrm{OM}=0.37 \%)$, and in $\mathrm{N}, \mathrm{P}$ and $\mathrm{K}$ (data not shown). The total concentrations for $\mathrm{Cu}, \mathrm{Pb}$ and $\mathrm{Zn}$ (Table 1) were high and largely exceeded both the typical concentrations for soils (Salomons and 
Table 1 Metal concentrations in the soil, mean \pm standard deviation $(\mathrm{SD}, n=3)$

\begin{tabular}{|c|c|c|c|c|c|c|}
\hline \multicolumn{5}{|c|}{ Metal concentrations } & \multicolumn{2}{|c|}{ Reference values $\left(\mathrm{mg} \mathrm{kg}^{-1} \mathrm{DW}\right)$} \\
\hline Element & $\begin{array}{l}\text { Total } \\
\left(\mathrm{mg} \mathrm{kg}^{-1} \mathrm{DW}\right)\end{array}$ & $\begin{array}{l}\text { Mobile fraction }^{\mathrm{a}} \\
\left(\mathrm{mg} \mathrm{kg}^{-1} \mathrm{DW}\right)\end{array}$ & $\begin{array}{l}\text { Mobilisable fraction }{ }^{\mathrm{b}} \\
\left(\mathrm{mg} \mathrm{kg}^{-1} \mathrm{DW}\right)\end{array}$ & $\begin{array}{l}\text { Soil leachate }{ }^{\mathrm{c}} \\
\left(\mathrm{mg} \mathrm{l}^{-1}\right)\end{array}$ & $\begin{array}{l}\text { Limit values } \\
\text { of Portuguese } \\
\text { legislation }^{\mathrm{d}}\end{array}$ & $\begin{array}{l}\text { Typical } \\
\text { values for } \\
\text { soil }^{\text {e }}\end{array}$ \\
\hline $\mathrm{Cd}$ & $2.6 \pm 0.2$ & $0.202 \pm 0.001$ & $0.17 \pm 0.01$ & $0.012 \pm 0.002$ & 1 & 0.6 \\
\hline $\mathrm{Cr}$ & $21.8 \pm 0.6$ & $0.68 \pm 0.04$ & $0.76 \pm 0.01$ & $0.096 \pm 0.004$ & 50 & 84 \\
\hline $\mathrm{Cu}$ & $362 \pm 23$ & $2.3 \pm 0.1$ & $4.4 \pm 0.1$ & $0.111 \pm 0.008$ & 50 & 26 \\
\hline $\mathrm{Ni}$ & $15.4 \pm 0.4$ & $0.73 \pm 0.01$ & $0.70 \pm 0.02$ & $0.04 \pm 0.01$ & 30 & 34 \\
\hline $\mathrm{Pb}$ & $1250 \pm 69$ & $2.9 \pm 0.1$ & $7.9 \pm 0.6$ & $0.106 \pm 0.008$ & 50 & 29 \\
\hline $\mathrm{Zn}$ & $254 \pm 64$ & $1.06 \pm 0.05$ & $1.0 \pm 0.2$ & $0.036 \pm 0.009$ & 150 & 60 \\
\hline
\end{tabular}

${ }^{\text {a }}$ Extracted by calcium chloride $0.01 \mathrm{M}$ solution

${ }^{\mathrm{b}}$ Extracted by ammonium acetate $0.5 \mathrm{M}$, acetic acid $0.5 \mathrm{M}$ and EDTA $0.01 \mathrm{M}$, pH 4.7 solution

c Metal concentrations in the soil leachate obtained according to DIN 38414-S4 (1984)

${ }^{\mathrm{d}}$ Limit concentrations for metals in farmed soils $(\mathrm{pH} \leq 5.5)$ allowed by the Portuguese legislation (Decreto-Lei no. 118/2006)

e Salomons and Förstner (1984)

DW: Dry weight

Förstner 1984) and the limit values for farmed soils allowed by Portuguese legislation. Nonetheless, the bioavailable fraction was very small, both for the mobile fraction and for the mobilisable fraction (Table 1). The metal content in the soil leachates was also very low, even smaller than the concentrations obtained using the weak electrolyte solutions. This could be explained by the fact that this soil was heavily exposed to weathering processes, which can also be noted on the soil characteristics reported. The soil leachate had a $\mathrm{pH}$ of 3.7, an EC of $0.015 \mathrm{~S} \mathrm{~m}^{-1}$ (low salinity) and the $\mathrm{pH}$ of $0.01 \mathrm{M} \mathrm{CaCl}_{2}$ settled soil suspension was 3.6.

All the metals studied were mainly associated with the residual fraction of the soil (Fig. 1). For $\mathrm{Cu}, \mathrm{Pb}$ and $\mathrm{Zn}$, the most abundant metals in this contaminated soil, more than $80 \%$ of the total metal content was in the residual fraction. The metal extracted by the first step (water-soluble, exchangeable, and weakly bound to OM) was less than $5 \%$ of the total content for $\mathrm{Cd}, \mathrm{Cr}, \mathrm{Cu}, \mathrm{Pb}$ and $\mathrm{Zn}$, and less than $10 \%$ for Ni. The fraction extracted by the first step is considered a relative empirical estimate of metal bioavailability (Kennedy et al. 1997), which is in agreement with the results obtained by the single-step extractions mentioned above. It is important to note that, although the total content for $\mathrm{Pb}$ in this soil was large $\left(1,250 \mathrm{mg} \mathrm{kg}^{-1} \mathrm{DW}\right)$, it was detected in two fractions: associated with $\mathrm{Fe}-\mathrm{Mn}$ oxides $(10 \%$ of the

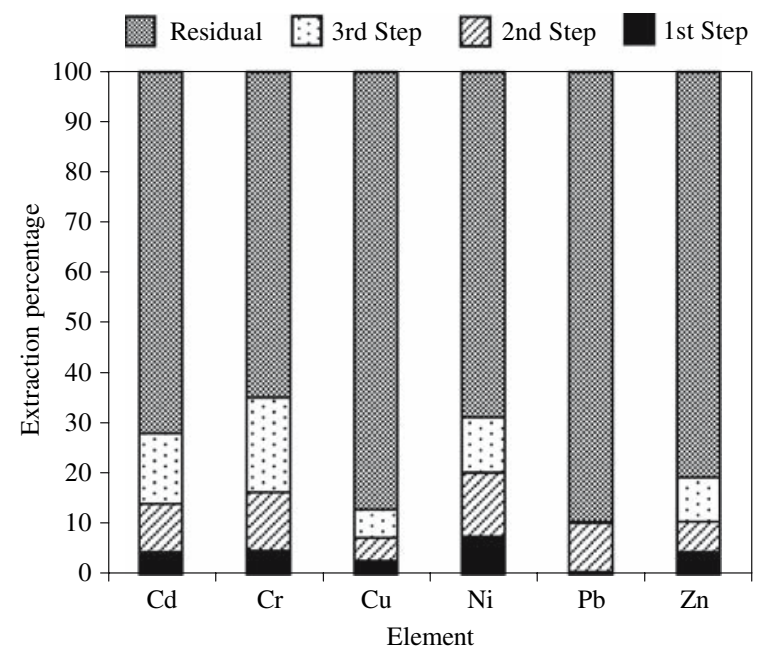

Fig. 1 Metals, as a percentage of the total content, after fractionation through the BCR procedure: first step (exchangeable fraction), second step (reducible fraction), third step (oxidizable fraction) and residual

total content, extracted in the second step) and in the residual fraction ( $89 \%$ of the total content), presenting the least bioavailability of the metals studied.

\section{Bioassays}

Cress growth was impaired (54\% relative growth) at $40 \%$ (v/v) soil concentration compared with the control without mine soil, but not for lower concentrations (5\%, 
$10 \%$ and 20\%) (Dunnet's test, $p<0.05$ ). Cress growth above the $50 \%(\mathrm{v} / \mathrm{v})$ concentration was negligible.

No earthworm mortality was observed after 14 days incubation, but earthworm biomass at the end of the test was smaller for the $100 \%(\mathrm{v} / \mathrm{v})$ soil concentration compared with the control without mine soil (Dunnet's test, $p<0.05$ ).

The mine soil was avoided by earthworms at concentrations $\geq 50 \%(\mathrm{v} / \mathrm{v})$, suggesting an impaired quality according to the definition of habitat function (ISO/CD 2003; Loureiro et al. 2005a), i.e. if the percentage of animals present in the soil is less than $20 \%$, the soil is considered to be toxic or with impaired quality.

There were no significant differences between relative seed germination (RSG) and relative root growth (RRG) of cress after exposure to various concentrations of the soil leachate (data not shown).

In the D. magna immobilization bioassay using the soil leachate, an $\mathrm{EC}_{50}$ of $36.3 \%$ (v/v) with a confidence interval (CI) of $34.5-38.3 \%$ was found, suggesting a considerable toxic effect of this soil on this organism.

In the luminescent bacteria bioassay the observed toxic effect was insufficient to allow the calculation of an $\mathrm{EC}_{50}$, but $\mathrm{EC}_{20}$ values were estimated: $\mathrm{EC}_{20}(15 \mathrm{~min})=$ $45.2 \%(\mathrm{CI}=45.0-45.5 \%)$ and $\mathrm{EC}_{20}(30 \mathrm{~min})=10.7 \%$ $(\mathrm{CI}=10.4-11.0 \%)$, all in $\mathrm{v} / \mathrm{v}$.

It is important to note that the results obtained in both indirect exposure bioassays were achieved with a $\mathrm{pH}$ correction on the soil leachate to $7.0 \pm 0.2$, as specified in the respective methods.

\section{Discussion}

The results show that, despite the high total metal concentrations, the bioavailable fractions were very small. This fact was corroborated by the sequential extraction, which showed that all the studied metals were mainly found in the residual fraction of the soil. The only obvious soil constraint was its acidity. Relying only on physicochemical analysis, it could be concluded that this soil had low toxicity. However, some of the ecotoxicity bioassays were very sensitive to this type of mine soil and were able to detect soil toxicity.

As expected, results from the bioassays were strongly dependent on the sensitivity of the organism used. Some tests (earthworm mortality and seed germination) were less sensitive to this particular type of soil contamination, whereas plant growth and D. magna immobilization bioassays were much more sensitive. Chaîneau et al. (2003) reached similar conclusions when using the same tests to evaluate the bioremediation of a crude-oil-polluted soil. In their case, bacterial luminescence (Microtox) was also considered a very sensitive test. In our study, the low sensitivity of this test was probably due to the correction of the leachate to $\mathrm{pH} 7.0$, which is part of the standard method (ISO 11348-2 1998), but masked a major soil constraint.

Loureiro et al. (2005b), using aquatic bioassays to evaluate the toxicity of two mine soils, found that marine bacteria were more sensitive to eluates from the soil with low heavy metal content than to eluates from the soil with high heavy metal content, while D. magna was sensitive to both soil eluates. Considering these facts and our results, we assumed that the D. magna immobilization bioassay would be more sensitive to this type of soil contamination.

As for the direct toxicity bioassays, it was obvious that the mine soil had an impact on plant growth. These effects were probably due not only to metals present in the soil and its acidity, but also to the lack of proper structure and deficient porosity. The avoidance behaviour bioassay using E. fetida also proved to be a sensitive test to be used in this type of mine soil and was adequate to obtain fast answers with low costs, suggesting it should be used as a screening tool to assess soil contamination or its remediation.

In conclusion, the direct bioassays (plant growth using L. sativum and avoidance behaviour using E. fetida), which test soil habitat function, as well as the aquatic bioassays (D. magna immobilization and luminescence inhibition in $V$. fischeri), which test soil retention function, proved to be adequate to assess the quality of these mine-contaminated soils.

Acknowledgement The authors would like to thank "Fundação para a Ciência e Tecnologia" for financial support through the Project POCI/AMB/57586/2004, with partial funding from the FEDER.

\section{References}

ASTM E 1676-97 (1997). American Society for Testing and Materials. Standard guide for conducting laboratory soil toxicity or bioaccumulation tests with Lumbricid earthworm Eisenia fetida. In Annual Book of ASTM Standards (pp. 1056-1074). West Conshohoken, PA. 
Chaîneau, C. H., Yepremian, C., Vidalie, J. F., Ducreaux, J., \& Ballerini, D. (2003). Bioremediation of a crude oil-polluted sol: Biodegradation, leaching and toxicity assessments. Water, Air and Soil Pollution, 144, 419-440.

Decreto-Lei no. 118/2006, de 21 de Junho. Diário da República no. 118/2006-I Série A. Ministério do Ambiente, do Ordenamento do Território e do Desenvolvimento Regional. Lisboa.

DIN 38 414-S4 (1984). Determination of leachability by water (S4). German standard methods for the examination of water, wastewater and sludge. Sludge and sediments (group S).

Fuentes, A., Lloréns, M., Sáez, J., Aguilar, M. I., Ortuño, J. F., \& Meseguer, V. F. (2004). Phytotoxicity \& heavy metals speciation of stabilized sewage sludges. Journal of Hazardous Materials, A108, 161-169.

Gupta, S. K., Vollmer, M. K., \& Krebs, R. (1996). The importance of mobile, mobilisable and pseudo total heavy metal fractions in soil for three-level risk assessment and risk management. The Science of the Total Environment, 178, 11-20.

Hamilton, M. A., Russo, R. C., \& Thurston, R. V. (1977). Trimmed Spearman-Karber method for estimating median lethal concentrations in toxicity bioassays. Environmental Science and Technology, 11(7), 714-719. Correction (1978). 12(4), 417.

Hammer, D., \& Keller, C. (2002). Changes in the rhizosphere of metal-accumulating plants evidenced by chemical extractants. Journal of Environmental Quality, 31, 1561-1569.

Houba, V. J. G., Lexmond, T. M., Novozamsky, I., \& van der Lee, J. J. (1996). State of the art and future developments in soil analysis for bioavailability assessment. The Science of the Total Environment, 178, 21-28.

ISO 6341 (1996). Water quality-Determination of the inhibition of the mobility of Daphnia magna Staus (Cladocera, Crustacea) - acute toxicity test. International Organisation for Standardisation. Geneva, Switzerland.

ISO 11348-2 (1998). Water quality-Determination of the inhibitory effect of water samples on the light emission of Vibrio fischeri (Luminescent bacteria test). Part 2: Method using liquid-dried bacteria. International Organisation for Standardisation. Geneva, Switzerland.

ISO 11466 (1995). Soil quality-Extraction of trace elements soluble in aqua regia. International Organisation for Standardisation. Geneva, Switzerland.

ISO/CD (2003). Soil Quality-Avoidance test for testing the quality of soils and the toxicity of chemicals-Test with earthworms (Eisenia fetida). ISO 17512. International Organization for Standardization. (p. 26). Geneva, Switzerland.

ISO/DIS 15799 (1999). Soil Quality-Guidance on the ecotoxicological characterization of soils and soil materials.
Annex A.1.2.2 Determination of the effects of pollutants on soil flora-Part 2: Effects of chemicals on the emergence and growth of higher plants. International Organisation for Standardisation. Geneva, Switzerland.

Kennedy, V. H., Sanchez, A. L., Oughton, D. H., \& Rowland, A. P. (1997). Use of single and sequential chemical extractants to assess radionuclide and heavy metals availability from soils to root uptake. Analyst, 122, 89R-100R.

Loureiro, S., Soares, A. M. V. M., \& Nogueira, A. J. A. (2005a). Terrestrial avoidance behaviour tests as screening tool to assess soil contamination. Environmental Pollution, 138, 121-131.

Loureiro, S., Ferreira, A. L. G., Soares, A. M. V. M., \& Nogueira, A. J. A. (2005b). Evaluation of the toxicity of two soils from Jales Mine (Portugal) using aquatic bioassays. Chemosphere, 61, 168-177.

Pueyo, M., López-Sanchez, J. F., \& Rauret, G. (2004). Assessment of $\mathrm{CaCl}_{2}, \mathrm{NaNO}_{3}$ and $\mathrm{NH}_{4} \mathrm{NO}_{3}$ extraction procedures for the study of $\mathrm{Cd}, \mathrm{Cu}, \mathrm{Pb}$ and $\mathrm{Zn}$ extractability in contaminated soils. Analytica Chimica Acta, 504, 217-226.

Quevauviller, P., van der Sloot, H. A., Ure, A., Muntau, H., Gomez, A., \& Rauret, G. (1996). Conclusions of the workshop: Harmonization of leaching/extraction tests for environmental risk assessment. The Science of the Total Environment, 178, 133-139.

Rauret, G., López-Sanchez, J. F., Sahuquillo, A., Barahona, E., Lachica, M., Ure, A. M., Davidson, C. M., Gomez, A., Lück, D., Bacon, J., Yli-Halla, M., Muntau, H., \& Quevauviller, P. (2000). Application of a modified BCR sequential extraction (three-step) procedure for the determination of extractable trace metal contents in a sewage sludge amended soil reference material (CRM 483), complemented by a three-year study of acetic acid and EDTA extractable metal content. Journal of Environmental Monitoring, 2, 228-233.

Sahuquillo, A., Rigol, A., \& Rauret, G. (2003). Overview of the use of leaching/extraction tests for risck assessment of trace metals in contaminated soils and sediments. Trends in Analytical Chemistry, 22(3), 152-159.

Salomons, W., \& Förstner, U. (1984). Metals in the hydrocycle. Berlin: Springer-Verlag.

Tessier, A., Campbell, P. G. C., \& Bisson, M. (1979). Sequential extraction procedure for the speciation of particulate trace metals. Analytical Chemistry, 51(7), 844-851.

van Gestel, C. A. M., van der Waarde, J. J., Derksen, J. G. M., van der Hoek, E. E., Veul, M. F. X. W., Bouwens, S., Rusch, B., Kronenburg, R., \& Stokman, G. N. M. (2001). The use of acute and chronic bioassays to determine the ecological risk and bioremediation efficiency of oilpolluted soils. Environmental Toxicology and Chemistry, 20(7), 1438-1449. 